\title{
Comparative Study of Landform Mapping Using Terrain Attributes and Topographic Position Index (TPI): a Case Study in Al-Alamien - Ras El-Hekma Region, Egypt

\author{
Sami Z. Mohamed ${ }^{1}$, , M. Bahnassy ${ }^{2}$, H. Gaber ${ }^{2}$, Kh. M. Darwish ${ }^{1}$
}

\begin{abstract}
The aim of this study is to compare the classification of the landscape of the area located between Al-Alamien and Ras El-Hekma to landform classes using two different classification methods; the terrain attributes method and the topographic position index (TPI) method. Terrain attributes classification method derived from a digital elevation model and were overlaid using cell statistics to generate a landform map with seven classes. The landform classes were: (1) Lower coastal plain (17.86\%), (2) Upper coastal plain $(43.61 \%)$, (3) Piedmont plain $(2.33 \%)$, (4) Dissected escarpment (2.64\%), (5) Plateau (26.79\%), (6) Ridges and coastal bars $(3.62 \%)$, and (7) Inland dunes (3.15\%). The topographic position index (TPI) method which generate the landform classes uses only the digital elevation model. The generated landform classes were: (1) Valleys $(2.1 \%)$, (2) Midslopes drainages and shallow valleys (1.1\%), (3) Plains $(92.77 \%)$, (4) Hills in plains (0.34\%), (5) Mesas (2.44\%), and (6) Ridges (1.25\%). The comparison of the two methods showed that using the terrain attributes method was more detailed.
\end{abstract}

Keywords: Landform Classification, Soil Catena, Terrain Attributes, Topographic Position Index (TPI), Digital Elevation Model (DEM)

\section{INTRODUCTION}

Landforms can be understood as a geomorphological integral part of the landscape (Barker, 2009), they reflect the influence of geology and climate on a global or regional scale (Strahler, 2008). The integration of landform and climate is obviously affects the development of soils. The significance of landform studies in terms of understanding the potential and constraints within the landscape associated with them, is well documented (Wiens et al., 2007). From a geological perspective, landforms were created by geological processes, (Drescher and Frey, 2009). Landform study imparts itself to the fields of hydrology, pedology, and environmental studies. Landforms can be used to obtain a general impression of soil forming processes, due to its significant role in the current sedimentary processes, (Chabala et al., 2013). Soil catena conceives that soil is a function of topography, therefore, classifying the terrain into landform classes, is essential to understand the soil pattern (Young and. Hammer, 2000). The landform digital mapping can be performed using digital elevation models (DEMs) derived from remote sensing or conventionally from contour lines and spot heights. Although several methods of landform classification have been applied, the absence of standards (MacMillan, 2011), the applied classifications has to be modified according to the local environment.

This present study aims to integrate landform classification of Al-Alamien - Ras El-Hekam region, using two different classification methods (The terrain attributes and Topographic Position Index (TPI)), and derive landform classes to indicate or suggest marked differences in local topography and geomorphology.

\section{MATERIALS AND METHODS}

\section{1-Study area:}

The study area is located in Matrouh Governorate, along the north western part of Egypt on the Mediterranean coast (Figure 1). The study site covers an area of approximately $2230 \mathrm{~km}^{2}$, and extends between longitudes $28^{\circ} 54^{\prime} 9.68^{\prime \prime}$ to $27^{\circ} 29^{\prime} 51.47^{\prime \prime} \mathrm{E}$ and latitudes $30^{\circ} 52^{\prime} 44.48^{\prime \prime}$ to $31^{\circ} 2^{\prime} 7.08^{\prime \prime} \mathrm{N}$. The study area is stretched along 3 districts: Al-Alamien, Dabaa and Marsa Matrouh, with the Mediterranean Sea is the northern border while El-Gaish road is the southern border. The study area has a Mediterranean climate characterized by mild and rainy winter and warm summer extends from May to September, (UNEP, 1995). The area's elevation ranges from $0 \mathrm{~m}$ to $180 \mathrm{~m}$ above the sea level. The geology of the study area according to the geological map of Egypt, has 3 geological surfaces, (1) Undivided Quaternary is exposed in wadis, represented by limestone, (2) Middle Miocene forming the surface beds of the tableland represented by biogenic carbonates with marl and shale, and (3) Pilocene represented by Oolitic limestone, sandstone with chalky limestone and gypsum.

\footnotetext{
${ }^{1}$ Land and Water Technologies Department, Arid Land Cultivation

Research Institute, City of Scientific Research and Technological Applications,

Alexandria, Egypt

2- Soil and Water Sciences Department, Faculty of Agriculture, Alexandria University, Egypt

E-Mail: eng.sami87@gmail.com

Received OCTOBR 21, 2018, Accepted November 13, 2018
} 


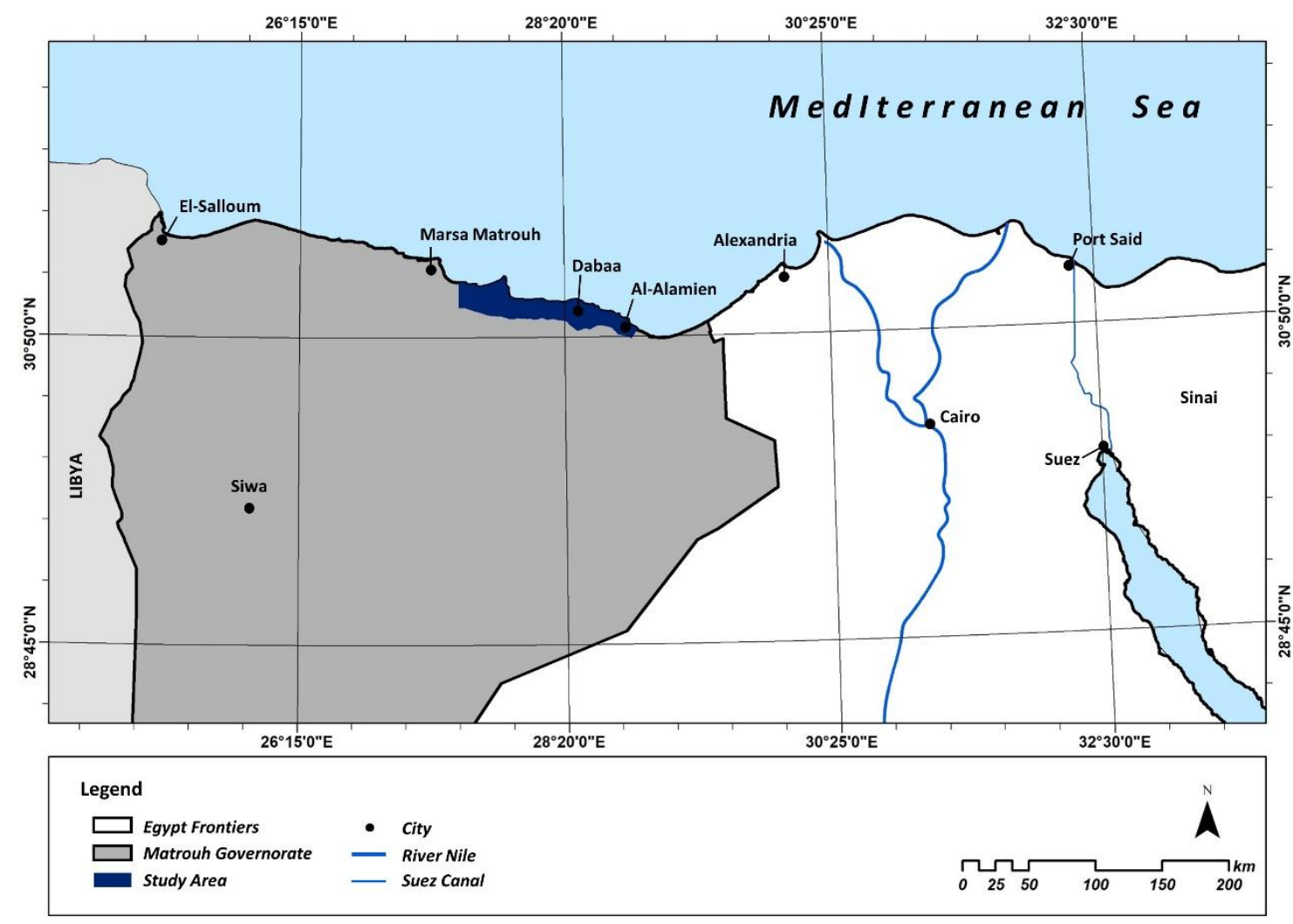

Figure 1. Study area location

\section{2-Landform classification process using terrain attributes:}

Landform classification reflects the terrain attributes of the landscape. Terrain attributes can be overlain in order to develop the landform classes. The landform classification was done using the method presented by Chabala et al., 2013. Figure 2, shows the process model for extraction of terrain attribute from digital elevation model (DEM) to produce landform map. The selected attributes were elevation, slope, relief intensity, and curvature. The extraction of terrain attributes and generation of the landform map was implemented in ArcGIS 10.3 software.

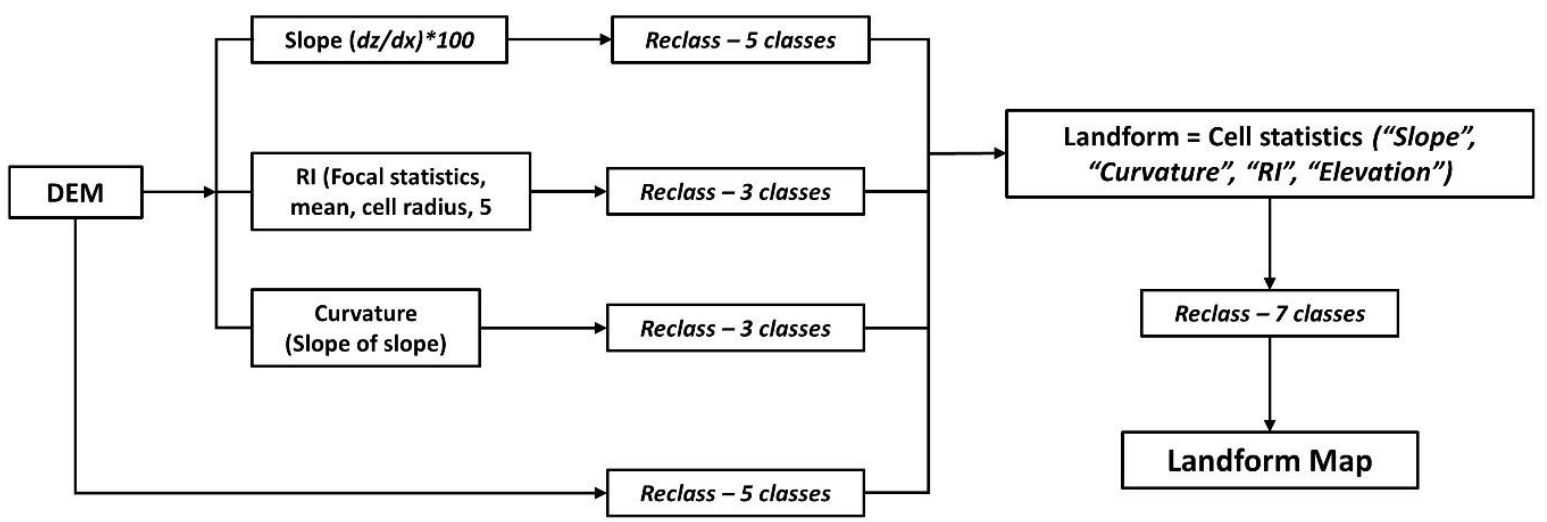

Figure 2. Process model for extraction of terrain attributes and landform classification 


\section{Digital Elevation Model (DEM):}

Twenty-three topographic maps scaled 1:25000, (Figure 3) were scanned and acquired in digital format, georeferenced in ArcGIS 10.3 software using Universal Transverse Mercator (UTM) coordinate system, to create the mosaic of the study area. 983 Contour lines and 10943 spot heights were digitized from the final mosaicked 23 topographic maps of the study area, to develop a Digital Elevation Model (DEM), using the Topo to Raster tool, which is an interpolation method designed for developing correct digital elevation models (DEMs) utilizing contour lines and spot heights (Hutchinson et al., 2011). The elevations were reclassified to 5 classes, based on field observations as shown in (Table 1).
Table 1. Digital Elevation Model (DEM) classes (m)

\begin{tabular}{cc}
\hline & Elevations $(\mathbf{m})$ \\
\hline Class & Description \\
\hline 1 & $0-35$ \\
2 & $35-70$ \\
3 & $70-105$ \\
4 & $105-140$ \\
5 & $140-180$ \\
\hline
\end{tabular}

Slope:

Slope is an important aspect of the landscape and functions as an input in the landform classification process which has been applied in a number of studies (Chabala et al., 2011; Dobos et al., 2005; Huting et al., 2008; Iwahashi and Pike, 2006 and Saadat et al., 2008). It is a measure that denotes the change in steepness of the surface over the horizontal plane. Slope was developed using ArcGIS 10.3, based on the average maximum technique. The developed slope was then reclassified into 5 classes based on the FAO guidelines for soil description, 2006 (Table 2).

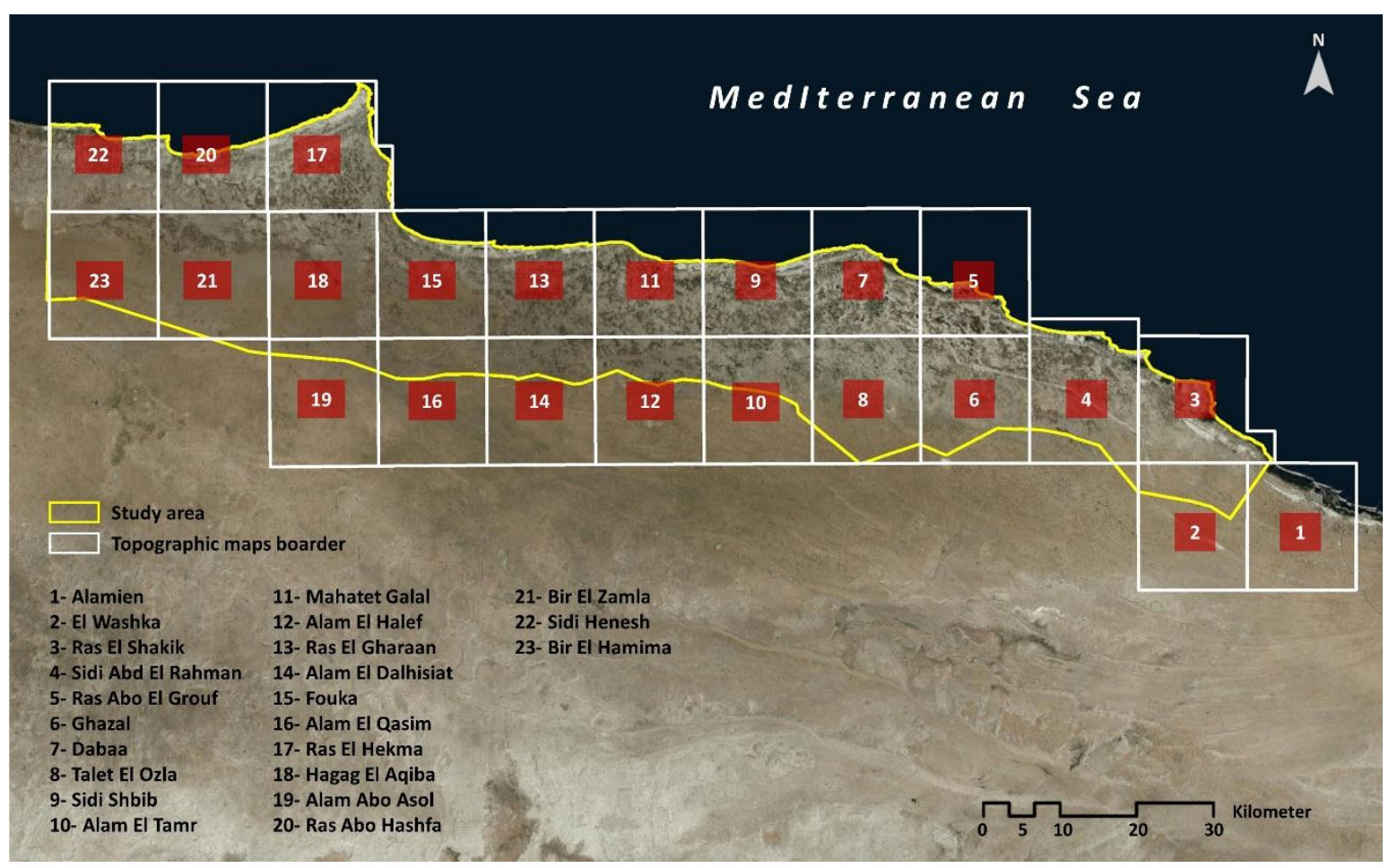

Figure 3. Topographic maps covering the study area 
Table 2. Slope gradient (\%) classes

\begin{tabular}{ccc}
\hline & \multicolumn{2}{c}{ Slope Gradient (\%) } \\
\hline Class & Slope \% & Description \\
\hline 1 & $0-0.2$ & Flat \\
2 & $0.2-5$ & Gently sloping \\
3 & $5-10$ & Sloping \\
4 & $10-15$ & Strongly sloping \\
5 & $15-45$ & Moderately steep \\
\hline
\end{tabular}

\section{Relief intensity (RI):}

Relief intensity (RI) refers to the changes in elevation between the lowest and highest points over a specific area of the landscape. The process of the extraction of the RI was based on the algorithm described by Dobos et al., 2005, using the focal statistics tool in ArcGIS 10.3. The focal statistics tool calculates the average value for each input cell location in a circular neighborhood with a radius of 5 cells (The pixel size (cell) was adjusted to $30 \mathrm{~m}$ ). The generated RI was reclassified to 3 classes of relief intensity as showen in (Table 3).

Table 3. Relief intensity (m) classes - Altitude range in 5 cell diameter

\begin{tabular}{cc}
\hline & Relief Intensity (m) \\
\hline Class & Description \\
\hline 1 & $<46$ \\
2 & $46-101$ \\
3 & $101-167$ \\
\hline
\end{tabular}

\section{Curvature:}

Curvature can be defined as curves of a surface and can be represented as profile, plan or general curvature (Thorne et al., 1987). General curvature is the curvature of the surface itself and is the second derivative of $\mathrm{Z}$ (elevation) with respect to $S$ (aspect) or the slope of the slope. According to Wilson and Gallant, 2000, the general curvature $(\mathrm{K})$ can be derived from the equation below:

$$
Z=Z^{2} x+2 Z^{2} x y+Z^{2} y
$$

The curvature was calculated with the curvature tool in ArcGIS 10.3. The tool calculates the second derivative value of the elevation grid (DEM) on a cell by cell basis and fitted to a surface composed of a $3 \times 3$ window. The output curvature was then classified to 3 classes to represent peaks shapes, concave shapes and flat surfaces. The classified curvature values are shown in (Table 4).
Table 4. Curvature classes

\begin{tabular}{ccc}
\hline \multicolumn{3}{c}{ Curvature } \\
\hline Class & Range & Description \\
\hline 1 & $-2.43-0.01$ & Concave \\
2 & $0.01-0.06$ & Flat surfaces \\
3 & $0.06-1.43$ & Peaks \\
\hline
\end{tabular}

\section{Landform Generation:}

The landform map was generated by overlaying the reclassified attributes representing relief intensity, curvature, elevation and slope (\%). This was performed by using the cell statistics tool in ArcGIS 10.3, with the mean set as the overlay statistic. The expression for the operation is given as:

Landforms = CellStatistics (["Slope", "Curvature", "Elevation", "Relief Intensity"])

The output from the cell statistic tool was a continuous grid which was classified into 7 landform classes according to the field observation and the literature describing the north western coast. The continuous classified grid was smoothed to remove the tiny isolated pixels.

\section{Landform classification process using topographic position index (TPI):}

Topographic position index (TPI) measures the difference between elevation at the central point of a neighborhood and the average elevation around it within a predetermined radius (Wilson and Gallant, 2000; Weiss, 2001). The higher index values represent the areas with higher elevation than surroundings pixels and the lower values characterized as valleys which are lower than surroundings, zero values represents flat areas or areas with a constant slope. The degree to which the cell value is higher or lower, plus the slope of the cell, can be used to classify the cell into slope position. If it is significantly higher than the surrounding neighborhood, then it is likely to be at or near the top of a hill or ridge. Significantly low values suggest the cell is at or near the bottom of a valley. TPI values near zero could mean either a flat area or a mid-slope area, so the cell slope can be used to distinguish the two, (Weiss 2001).

The TPI can be calculated according to the formula presented below using ArcGIS platform:

$$
\mathrm{TPI}_{\mathrm{i}}=\mathrm{T}_{0}-\frac{\left(\sum_{\mathrm{n}-1} \mathrm{~T}_{\mathrm{n}}\right)}{n}
$$


Where $\mathrm{T}_{0}$ elevation of the model point under evaluation, $T_{n}$ elevation of grid and $n$ the total number of surrounding points employed in the evaluation. With combining TPI at small and large scales a variety of nested landforms could be distinguished automatically, (Weiss, 2001).

\section{RERSULTS AND DISCUSSION}

Landform classification using terrain attributes method:

The landform classification presented in this study was based on terrain attributes. The elevation, slope gradient (\%), relief intensity and curvature maps where prepared based on the digital elevation model developed from contour lines and spot heights extracted from the topographic maps scaled 1:25000. Based on (Figure 4), the study area elevation is between $0 \mathrm{~m}$ to $180 \mathrm{~m}$ Above Sea Level (A.S.L), and where classified to 5 classes (Table 5). The dominant elevation class that occupies 30 $\%$ of the study area ranges from 35 to $70 \mathrm{~m}$ A.S.L.

The study area was classified into five slope gradient classes based on FAO guidelines for soil description, 2006, (Table 6 and Figure 5). It is obvious that the majority of the study area lies in the gently sloping class with an area $87 \%$ of the total study area.

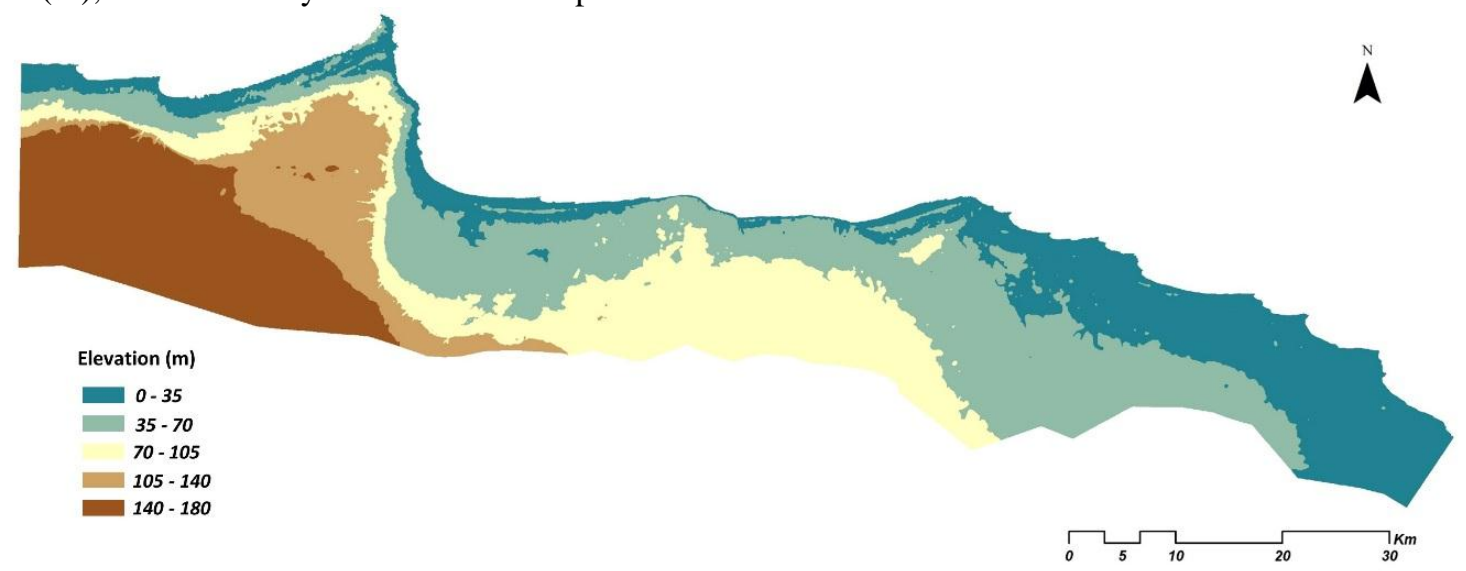

Figure 4.The classified digital elevation model (DEM)

Table 5.Digital Elevation Model (m) classes and their areas percentages of the study area

\begin{tabular}{cccc}
\hline & & Elevations $(\mathbf{m})$ & \\
\hline Class & Elevation $(\mathbf{m})$ & Area ha & \% \\
\hline 1 & $0-35$ & 50844 & 22.8 \\
2 & $35-70$ & 66900 & 30 \\
3 & $70-105$ & 45715 & 20.5 \\
4 & $105-140$ & 21185 & 9.5 \\
5 & $140-180$ & 38356 & 17.2 \\
\hline
\end{tabular}

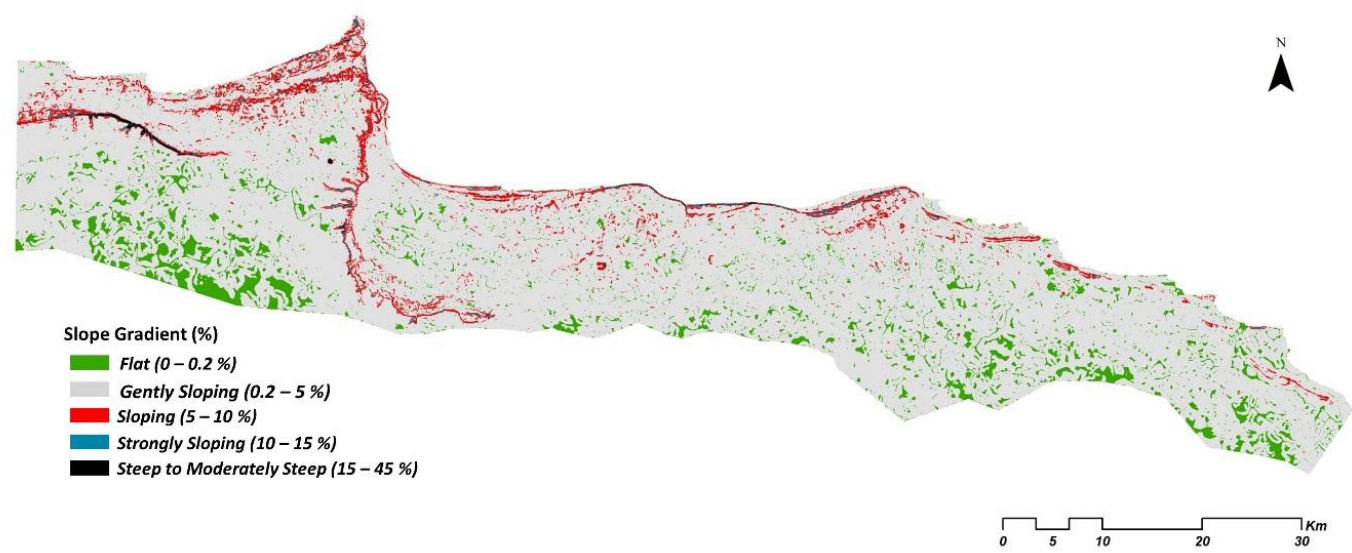

Figure 5. The classified slope gradient (\%) 
Table 6. Slope gradient (\%) classes and their areas percentages of the study area

\begin{tabular}{ccccc}
\hline \multicolumn{5}{c}{ Slope Gradient (\%) } \\
\hline Class & Slope \% & Description & Area ha & \% \\
\hline 1 & $0-0.2$ & Flat & 17862.3 & 8.01 \\
2 & $0.2-5$ & Gently sloping & 194010 & 87 \\
3 & $5-10$ & Sloping & 9499.8 & 4.26 \\
4 & $10-15$ & Strongly sloping & 1226.5 & 0.55 \\
5 & $15-45$ & Moderately steep & 401.4 & 0.18 \\
\hline
\end{tabular}

Relief intensity after applying the focal statistics the relief value is between $<45 \mathrm{~m}$ to $167 \mathrm{~m}$. Table 7 and Figure 6, show the spatial distribution of the changes in elevation between the lowest and highest points RI over the study area.

The curvature values were between -2.43 to 1.34 . The classification of the curvature (Table 8 and Figure 7) was according the $K$ value. Flat surfaces from 0.01 to 0.06 which dominating the majority of the curvature class with $93 \%$ of the total study area.

The landform classification map was developed using the overlaying technique by the cell statistics tool in ArcGIS 10.3 software, by overlaying the terrain attributes (elevation, slope gradient, relief intensity and curvature). Figure 8, shows the landform map, which consists of 7 classes: (1) Lower coastal plain, (2) Upper coastal plain, (3) Piedmont plain, (4) Dissected escarpment, (5) Plateau, (6) Ridges and coastal bars, and (7) Inland dunes. In general, different types of landform occur with increasing slope and elevation. It can be noticed that the lower and upper coastal plains are dominating the whole northern part of the study area with increasing differences in the width to the south because of the increasing in the slopes, elevation and the curvature changes in the south of Ras El-Hekma region performing more landform classes. Therefore, using the layers of slope, elevation, relief and curvature are effective layers for preparing the landform classification map. An area (\%) and terrain attributes comparisons were calculated for each landform classes and the results are shown in Table 9.

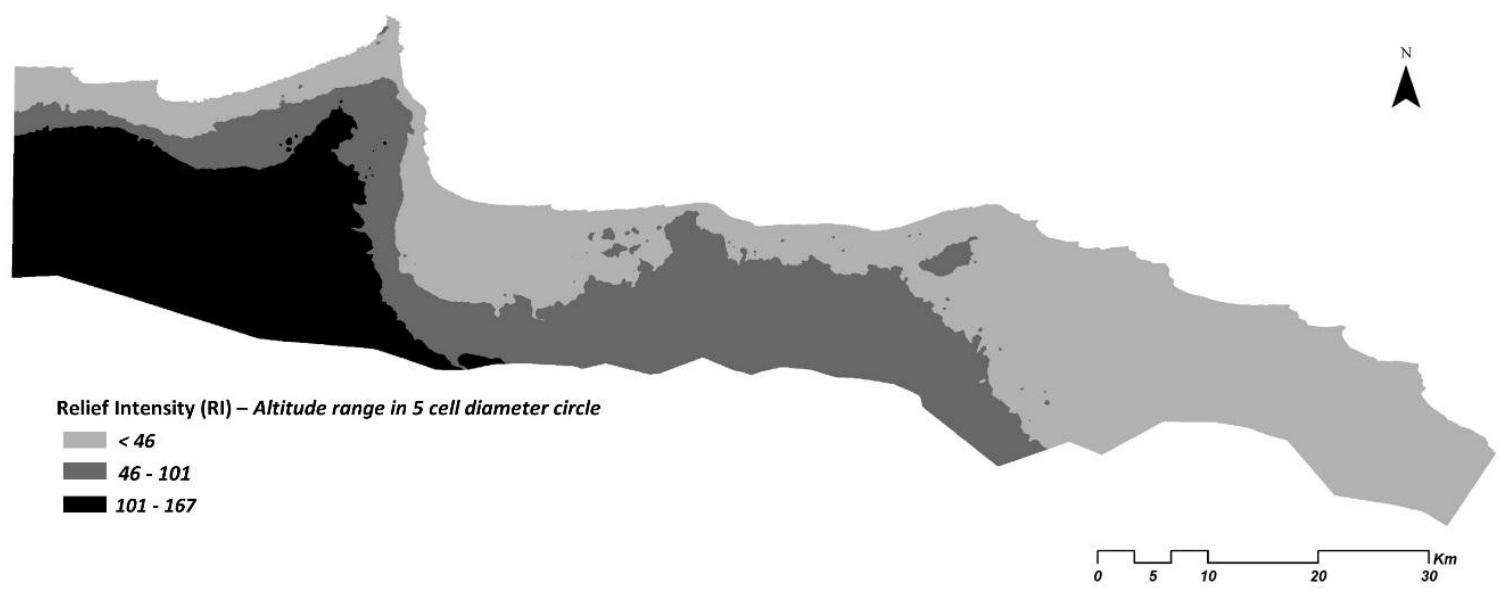

Figure 6. The classified relief intensity (RI)

Table 7. Relief intensity (m) classes and their areas percentages of the study area

\begin{tabular}{cccc}
\hline & & Relief Intensity RI $(\mathbf{m})$ & \\
\hline Class & RI $(\mathbf{m})$ & Area ha & \% \\
\hline 1 & $<46$ & 107040 & 48 \\
2 & $46-101$ & 62440 & 28 \\
3 & $101-167$ & 53520 & 24 \\
\hline
\end{tabular}




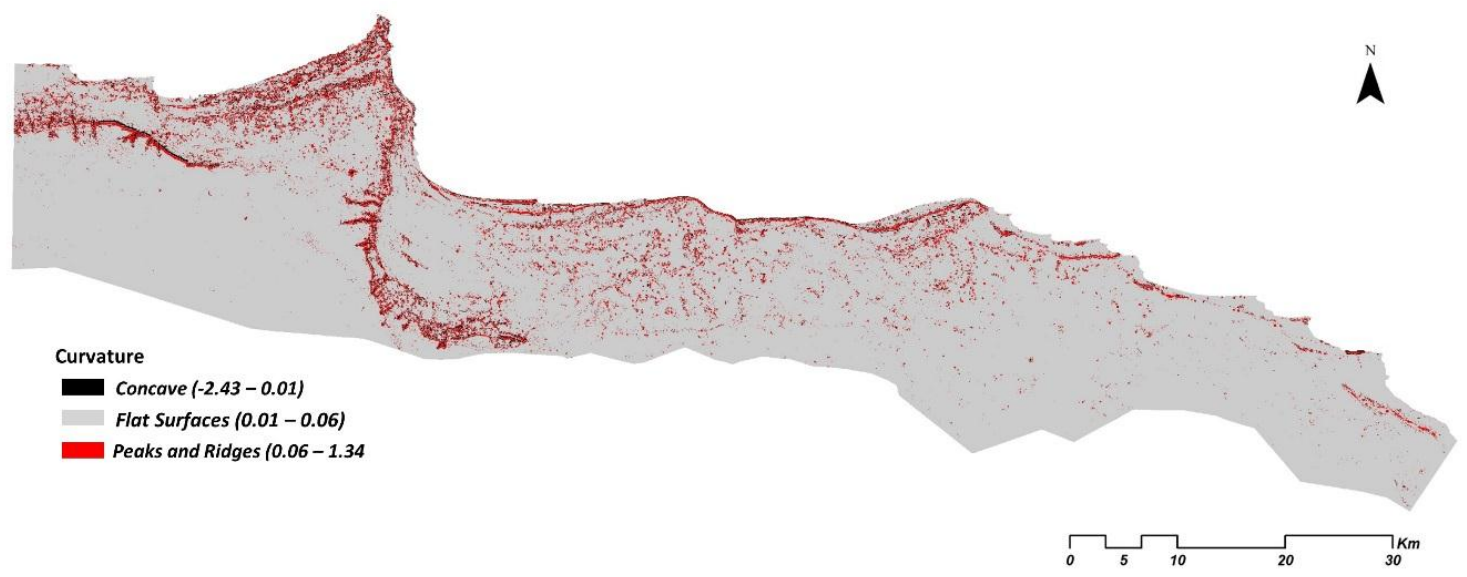

Figure 7. The classified curvature

Table 8. Curvature classes and their areas percentages of the study area

\begin{tabular}{ccccc}
\hline \multicolumn{5}{c}{ Curvature } \\
\hline Class & Range & Description & Area ha & \% \\
\hline 1 & $-2.43-0.01$ & Concave & 4460 & 2 \\
2 & $0.01-0.06$ & Flat surfaces & 207390 & 93 \\
3 & $0.06-1.34$ & Peaks & 11150 & 5 \\
\hline
\end{tabular}

Table 9. Characteristics of landform classes of the study area

\begin{tabular}{lccccc}
\hline Landform class & $\begin{array}{c}\text { Elevation } \\
(\mathbf{m})\end{array}$ & Slope (\%) & Curvature & Area (ha) & \% \\
\hline Lower coastal plain & $0-35$ & Flat to gently sloping & Flat surface & 39827.8 & 17.86 \\
Upper coastal plain & $35-70$ & Gently sloping & Flat surface & 97250.3 & 43.61 \\
Piedmont plain & $70-105$ & Sloping to strongly sloping & Flat surface & 5195.9 & 2.33 \\
Dissected escarpment & $105-130$ & Strongly sloping to steep slopes & Flat to peaky & 5887.2 & 2.64 \\
Plateau & $130-180$ & Flat slopes & Flat surface & 59741.7 & 26.79 \\
Ridges and coastal bars & Max 25 & Gently sloping & Peaky & 8072.6 & 3.62 \\
Inland dunes & Max 15 & Gently sloping & Peaky & 7024.5 & 3.15 \\
\hline
\end{tabular}

\section{Landform classification using topographic position index (TPI) method:}

The landform classification map was developed using the topographic position index (TPI) method using the TPI extension in the ArcGIS 10.3 platform. Figure 9, shows the landform map, which consists of 6 classes generated automatically by the TPI extension: (1) Valleys, (2) Mesas, (3) Hills in Plains, (4) Plains, (5) Midslopes Drainages and Shallow Valleys, and (6) Ridges. The results of the TPI classification indicated that most of the area are classified as plains with flat surfaces and dominated by $92.77 \%$ of the total study area, and the least percentage is classed as hills in plains occupying $0.34 \%$ of the study area as shown in Table 10.

The landform classification methods presented in this study showed that using the terrain attributes (elevation, slope, relief intensity and curvature) more detailed than the automated method (Topographic position index) which uses only the digital elevation

Table 10. Landform classes and their areas percentages of the study area

\begin{tabular}{lcc}
\hline Landform class & Area (ha) & \% \\
\hline Valleys & 4683 & 2.1 \\
Mesas & 5441.2 & 2.44 \\
Hills in Plains & 758.2 & 0.34 \\
Plains & 206877.1 & 92.77 \\
Midslopes Drainages and Shallow Valleys & 2453 & 1.1 \\
Ridges & 2787.5 & 1.25 \\
\hline
\end{tabular}




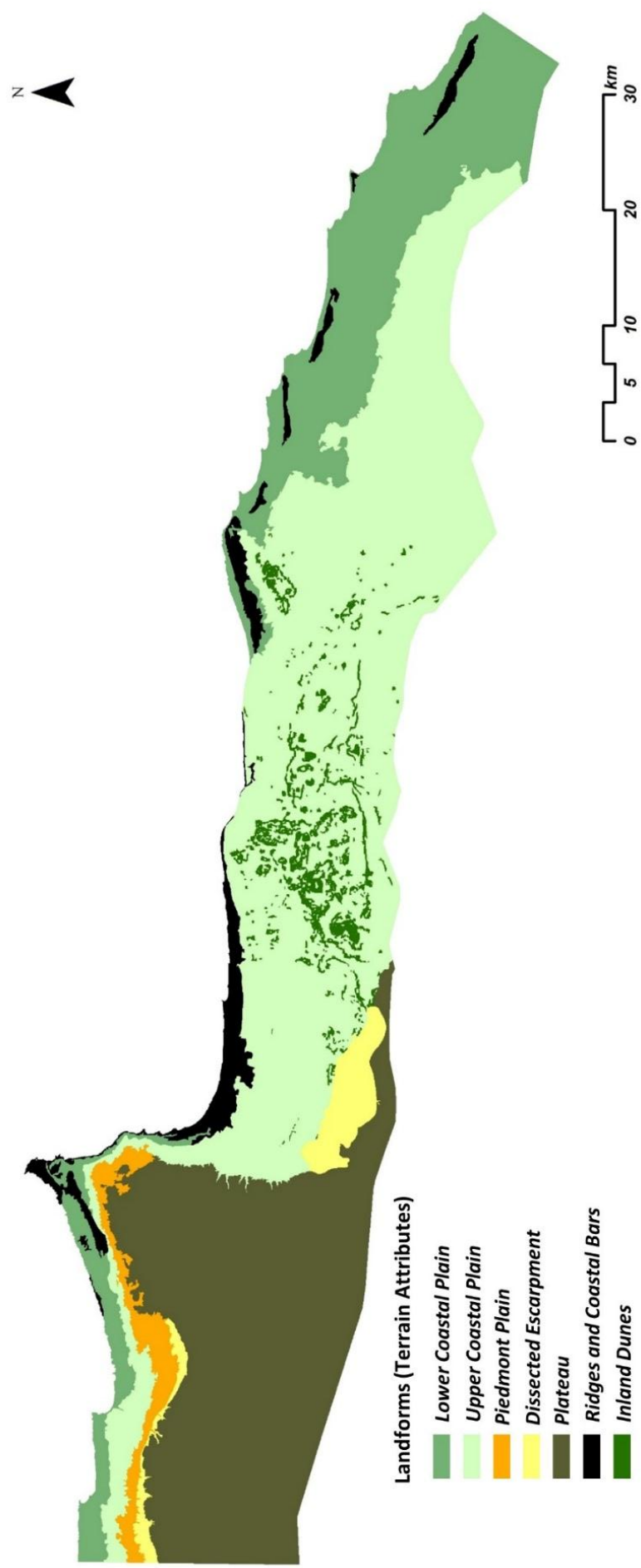

Figure 8. Landform map of the study area using terrain attributes method

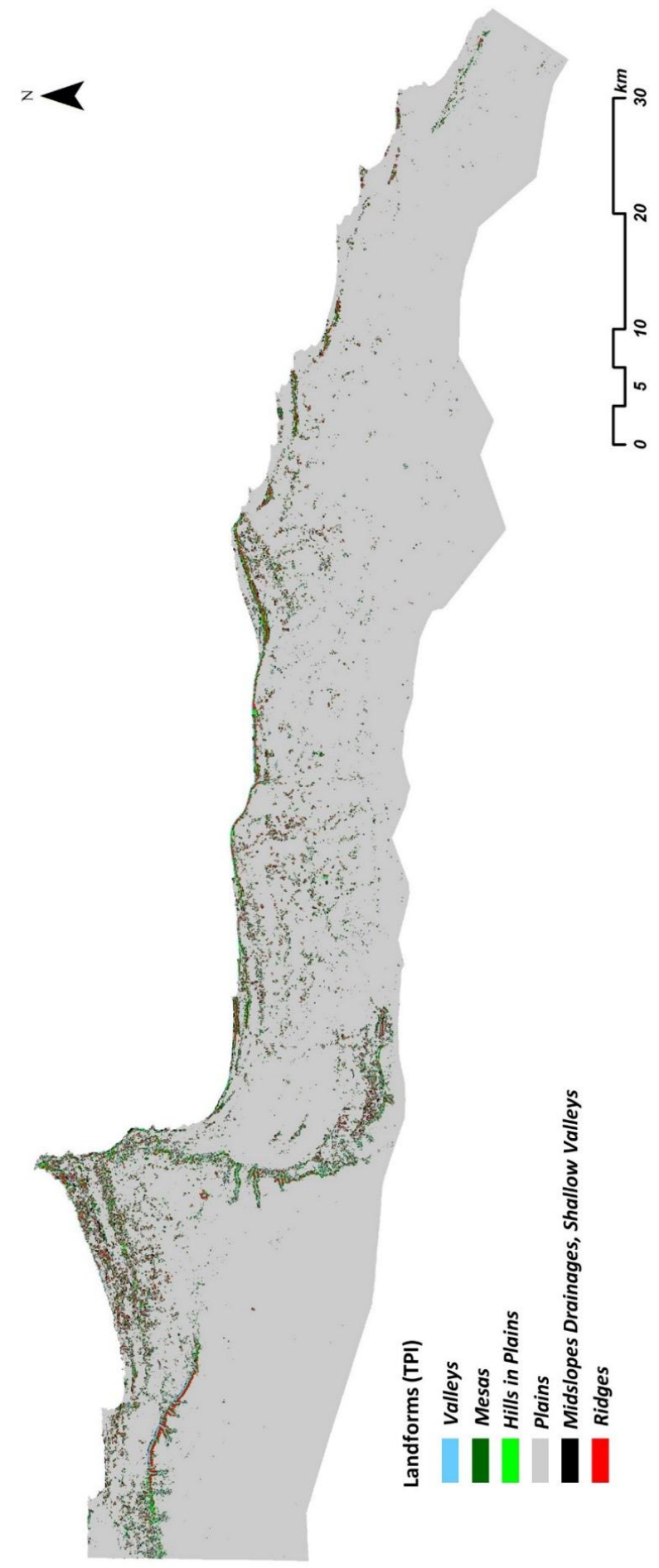

Figure 9. Landform map of the study area using TPI method 
model by measuring the difference between elevation at the central point of a neighborhood and the average elevation neighbor it within a predetermined radius (Wilson and Gallant, 2000; Weiss, 2001).

\section{CONCLUSION}

This research aims to compare two landform classification methods. Both methods depend on digital elevation models (DEMs). The terrain attributes method was highly effective and more smoothed in preparing a landform classification map, because of taking in consideration the real shape of the landscape, while the topographic position index (TPI) showed coarse results with one only dominated landform class (Plains) without taking in consideration the differences in the elevation between the flat surfaces. According the results presented in this research the terrain attributes method is more accurate and flexible in generating landform mapping which we can call it Supervised Landform Classification, while the generated landform can be classified to many different classes, but also, the accuracy of the elevation model highly effects the landform generated classes, also the researcher knowledge and experience of the study area and his software skills will affect the final result.

\section{REFERENCES}

Barker V.R. 2009. Introduction: Regional landform analysis. Avalaible online from Goddard Earth Sciences Data and Information Center.

Chabala, L.M., A. Mulolwa, and O. Lungu, 2013. Landform classification for digital soil mapping in the ChongweRufunsa area, Zambia. Agric. For. Fish, 2, pp.156-160.

Dobos, E., J. Daroussin and L. Montanarella, 2005. An SRTM-based procedure to delineate SOTER Terrain Units on 1:1 and 1:5 million scales. EUR $21571 \mathrm{EN}, 55 \mathrm{pp}$. Office for Official Publications of the European Communities, Luxembourg.

Drescher, K. and W.D. Frey, 2009. Landform classification using GIS. Position IT, pp.30-34.

Hutchinson, M.F., Xu, T. and Stein, J.A. 2011. Recent Progress in the ANUDEM Elevation Gridding Procedure. In: Geomorphometry 2011, edited by T. Hengel, I.S. Evans, J.P. Wilson and M. Gould, pp. 19-22. Redlands, California, USA.
Huting J.R.M., J. A. Dijkshoorn and V.W.P van Engelen, 2008. GIS procedures for mapping SOTERlandform for the LADA partner countries (Argentina, China, Cuba, Senegal and The Gambia, South Africa and Tunisia). ISRIC report 2008/04 and GLADA report 2008/02, ISRIC - World Soil Information and FAO, Wageningen (30 pp with data set).

Iwahashi J. and R.J.Pike. 2006. Automated classifications of topography from DEMs by unsupervised nested means algorithm and a three part geometric signature. Geomorphology 86, $409-440$.

FAO, 2006. Guidelines for soil description. Fourth Edition. FAO, Rome.

MacMillan, R., 2011. Automated extraction of land forms from DEM data. In Workshop presentation. Available from: www.slideshare.net/bob_macmillan/automatedextraction-of-landforms-from-dem-data-13062121.

Saadat H., R. Bonnell, F. Sharifi, M. Mehuys and S. AleEbrahim, 2008. Landform classification from digital elevation model and satellite imagery. Geomorphology 100, $453-464$.

Strahler, A.H., 2008. Modern physical geography. John Wiley $\&$ Sons.

Thorne, C.R, L. W. Zevenbergen, T.P. Burt, and D. P. Butcher, 1987. Terrain analysis for quantitative description of zero order basins. Ersosion and Sedimentation in the Pacific Rim. Proceedings of the Corvallis Symposium, August, 1987.

UNEP (1995). Guidelines for Integrated Management of Coastal and Marine Areas, UNEP Report 161.

Wiens, J.A., M.R. Moss, D. Mladenoff, and M.G. Turner, 2007. Foundation papers in landscape ecology. Columbia University Press.

Wilson J.P and J. C. Gallant. 2000. Terrain Analysis: Principles and Applications. John Wiley and Sons, Inc. Chichester, Canada

Weiss, A., 2001. Topographic positions and landforms analysis (conference poster). ESRI International User Conference. San Diego, CA, 2001; 9-13.

Young, F.J. and R.D. Hammer, 2000. Soil-landform relationships on a loess-mantled upland landscape in Missouri. Soil Science Society of America Journal, 64(4), pp.1443-1454. 


\section{الملخص العربي}

\section{دراسة مقارنة لإنتاج خرائط شكل سطح الأرض المات \\ بإستخدام طريقتى صفات التضاريس الأرضية و مؤثر الموقع الطبوغرافي:

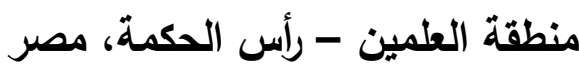

سامي زكي محمد، محمد بهنسي ، هثام جابر و خالد درويش

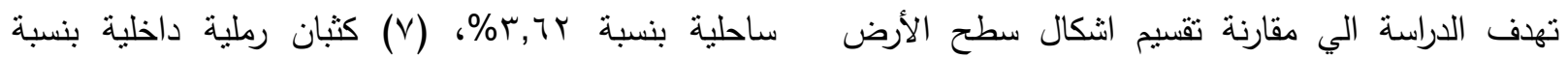

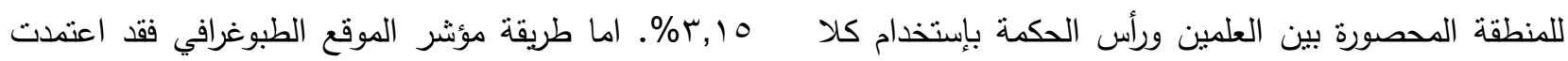

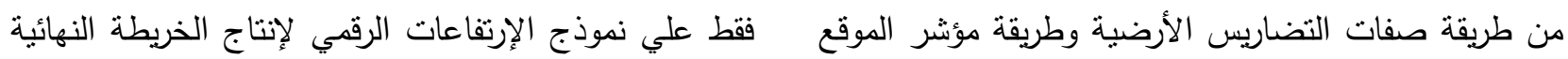

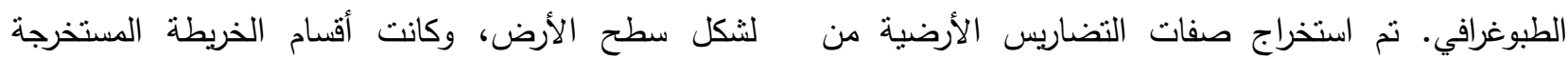

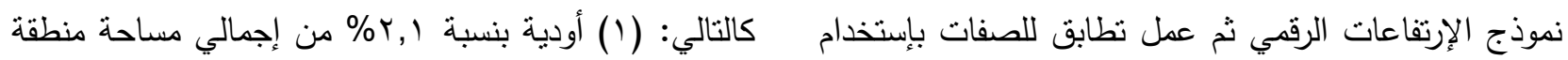

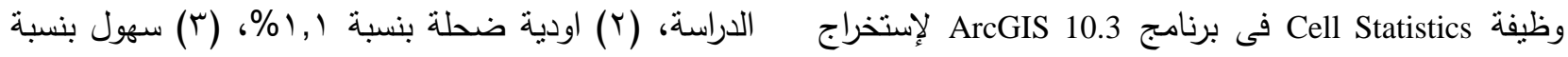

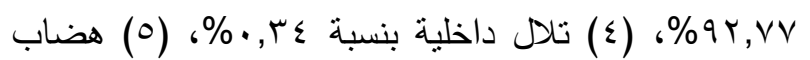
خريطة شكل سطح الأرض. وقد احتوت الخريطة النهائية

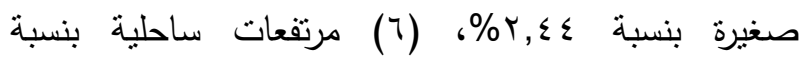
علي سبعة رتب وكانت علي النحو النالي: (1) سهل ساحلي

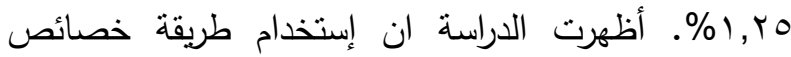

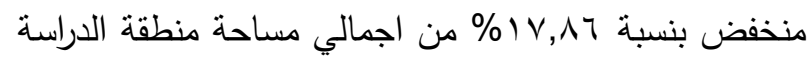
التضاريس الأرضية أكثر دقة وتفصيلا لانتاج خريطة شكل

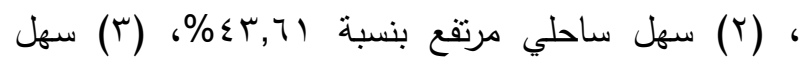

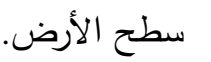

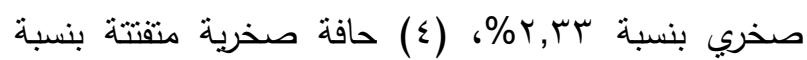

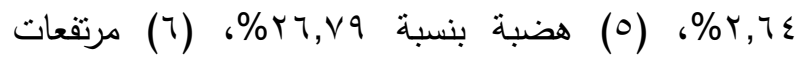

